\title{
Diabetes mellitus in normal pressure hydrocephalus
}

\author{
LAWRENCE JACOBS
}

From the Dent Neurologic Institute, Millard Fillmore Hospital, and Department of Neurology, State University of New York, School of Medicine at Buffalo, New York, USA

SUMMARY Seventeen of 33 patients $(51.5 \%)$ with normal pressure hydrocephalus were discovered to have diabetes mellitus. This was significantly greater than the $12.1 \%$ incidence found in agematched control subjects. The diabetes was not accounted for either by the patients' ages nor by their physical inactivity due to hospitalisation. Diabetes mellitus concurrent with normal pressure hydrocephalus may result from involvement of hypothalamic and brainstem autonomic structures by the expanding ventricles during the evolution of hydrocephalus.

The experiments of Claude Bernard in 1849 first indicated that the central nervous system plays an important role in the regulation of carbohydrate metabolism (Bernard, 1858). A large body of subsequent experimental findings support his observation (Banting et al., 1922; Sacks and MacDonald, 1925; Himwich and Keller, 1930; Macleod, 1934; David et al., 1935; Barris and Ingram, 1936; Anderson et al., 1952; Amand and Dua, 1955). However, there are only rare clinical examples in man in which diseases of the central nervous system are regularly associated with glucose abnormalities (Matthews, 1958; Steinke and Taylor, 1964; Schalch et al., 1970). In this study, a remarkably high incidence of diabetes mellitus was found in patients with the syndrome of normal pressure hydrocephalus. This is the first evidence that normal pressure hydrocephalus may be one of the unusual instances in which the brain's influence on glucose metabolism becomes manifest in a disease state.

\section{Patients and methods}

CLINICAL-RADIOGRAPHIC CRITERIA FOR DIAGNOSIS OF NORMAL PRESSURE HYDROCEPHALUS

The diagnosis of normal pressure hydrocephalus was made in 33 patients (50-84 years). In each case the

Supported in part by grants from the Harry M. Dent Family Foundation, Inc., and the Jacobs Family Foundation, Inc.

Address for reprint requests: Lawrence Jacobs, MD, Harry M. Dent Neurologic Institute, Millard Fillmore Hospital, 3 Gates Circle, Buffalo, New York 14209, USA.

Accepted 4 November 1976 diagnosis was made on the basis of the clinical picture and the radiographic findings. These patients had combinations of organic dementia (deficits of memory, orientation, calculations, reversals of serial orders, positive face-hand tests), motor dysfunction (gait disturbance, extrapyramidal), and incontinence. The presence of all three signs was not required for the diagnosis. The combinations of clinical signs are summarised in Table 1.

Table 1 Combinations of clinical signs in the 33 normal pressure hydrocephalus patients not previously suspected of having diabetes mellitus

\begin{tabular}{lc}
\hline Combinations of signs & Patients \\
\hline Dementia, motor dysfunction, incontinence & 18 \\
Dementia, motor dysfunction & 3 \\
Dementia, incontinence & 7 \\
Motor dysfunction, incontinence & 4 \\
Motor dysfunction & 1 \\
Total & -33 \\
\hline
\end{tabular}

Every patient underwent pneumoencephalography $(30-65 \mathrm{ml})$, and radioisotopic cisternography. The characteristic appearance of the pneumoencephalogram was essential for the diagnosis. There was always enlargement of the ventricles, with no air over the convexities of the cerebral hemispheres. There was never pneumoencephalographic evidence of cortical atrophy or obstruction of the ventriculoaqueductal system. Cisternography was performed by injection of radiopharmaceutical (iodinated 131I serum albumin in six, and ${ }^{169}$ ytterbium in 27 
patients) into the lumbar subarachnoid space. Serial images were obtained at four, 24 , and 48 hours in the lateral and anterior positions. The cisternograms were abnormal in every patient. Abnormal patterns were classified as (1) 'characteristic' of normal pressure hydrocephalus - ventricular stasis after 24 and 48 hours with no activity over the convexity-24 patients, or (2) 'mixed'-activity in the midline cisterns, or slow flow of activity in the Sylvian regions combined with some degree of ventricular retention-nine patients. The diagnosis of normal pressure hydrocephalus was not made if there was accumulation of radioactivity over the convexities or parasagittal regions after 24 and 48 hours. The clinical, radiographic, and surgical response profiles of 25 of these patients have been reported in detail elsewhere (Jacobs et al., 1976; Jacobs and Kinkel, 1976). Another five patients have subsequently undergone shunt surgery; three remain unoperated. Six other patients who fulfilled the clinical and radiographic criteria for the diagnosis of normal pressure hydrocephalus were known diabetics who were already taking medications. They were excluded from this study which was limited to normal pressure hydrocephalus patients who were not previously suspected of having diabetes mellitus.

\section{CRITERIA FOR DIAGNOSIS OF DIABETES MELLITUS}

Oral glucose tolerance tests (GTT) were conducted on every patient. The test was performed on 20 patients before cisternography, pneumoencephalography, or ventricular shunting procedures. Three patients underwent GTT after they had been discharged from hospital, and long after these stressful procedures had been performed $(24,28,36$ months), when the risk of a pseudodiabetic response was felt to be minimal. Patients were well fed on high caloric diets $(200 \mathrm{~g}$ of carbohydrate) for three days before the test. They drank Glucola solution, ( 75 g glucose, Ames) after an overnight fast. Collection of blood samples was by the Janney-Isaacson method (Helper, 1966), with blood drawn from the antecubital vein, and plasma glucose levels were determined by colorimetry (Dow). The plasma glucose values $(\mathrm{mg} / \mathrm{dl})$ were also converted into SI Units (mmol/l) (National Bureau of Standards, 1972). Fasting, one, two, and three-hour samples were drawn. The GTT were interpreted by the Wilkerson point system, with the critical values changed in accordance with the use of plasma rather than whole blood (Klimt et al., 1969). Scoring of glucose levels by this system is: Fasting $>130 \mathrm{mg} / \mathrm{dl}$ $=1$ point, one hour $>190 \mathrm{mg} / \mathrm{dl}=\frac{1}{2}$ point, two hour $>140 \mathrm{mg} / \mathrm{dl}=\frac{1}{2}$ point, three hour $>130 \mathrm{mg} / \mathrm{dl}=1$ point. The SI scoring is: Fasting $>7.2 \mathrm{mmol} / \mathrm{l}=1$ point, one hour $>10.5 \mathrm{mmol} / \mathrm{l}=\frac{1}{2}$ point, two hour $>$ $7.7 \mathrm{mmol} / \mathrm{l}=\frac{1}{2}$ point, three hour $>7.2 \mathrm{mmol} / 1=1$ point. The diagnosis of diabetes mellitus was made only if the patient's score was 2 or greater.

In addition, the two hour glucose levels were compared with a standardised nomogram which adjusts two hour whole blood glucose elevations in a large non-hospitalised population (Andres, 1971). The plasma levels were reduced by $14 \%$ for comparison with the whole blood glucose values (Zalme and Knowles, 1965).

Glucose tolerance tests (using the same criteria for the diagnosis of diabetes) were also conducted on 33 control subjects with non-neurological disorders. Control subjects were otherwise randomly selected. They were hospitalised for degenerative disc disease (eight), bone fracture (seven), and elective hernia surgery (six). Twelve had no medical illness at the time of the GTT and were awaiting placement in a nursing facility. The sex distribution of controls and normal pressure hydrocephalus patients was similar.

\section{Results}

Table 2 shows the two hour plasma glucose levels of normal pressure hydrocephalus and control patients Seventeen of the 33 normal pressure hydrocephalus patients $(51.5 \%)$ had elevated two hour levels an 12 을 fulfilled the other criteria for the diagnosis of diabete mellitus. Another nine had two hour elevations bug did not fulfil the other criteria for the diagnosis. Foup $(12.1 \%)$ of the control patients had two hour eleva tions and other criteria indicating diabetes; anothe six had elevations of the two hour glucose, but did not fulfil the other criteria for the diagnosis. The incidence of diabetes was significantly different in the two groups $(P<0.01)$. When abnormal GTT occurred, the degree of plasma glucose elevation was greatest in normal pressure hydrocephalus patients. The average two hour level in patients considered diabetic was $233 \mathrm{mg} / \mathrm{dl}$ (range $168-400 \mathrm{mg} / \mathrm{dl}$ ) in normal pressure hydrocephalus patients, and $197 \mathrm{mg} / \mathrm{dl}$ (range 173-214 $\mathrm{mg} / \mathrm{dl}$ ) in controls (not significant). The average SI two hour value was $12.8 \mathrm{mmol} / \mathrm{l}$ (range 9.2-22.2 $\mathrm{mmol} / \mathrm{l}$ ) in normal pressure hydrocephalus patients, and $10.8 \mathrm{mmol} / \mathrm{l}$ (range $9.5-11.8 \mathrm{mmol} / \mathrm{l}$ ) in controls. Comparison of the corrected-that is, $14 \%$ reduction-plasma two hour glucose levels to the ageadjusted nomogram based on whole blood glucose levels showed an average percentile ranking of $17.2 \%$ (range $0-49 \%$ ) for the normal pressure hydrocephalus patients, and $30.5 \%$ (range $17-50 \%$ ) for the controls. Thus, $82.8 \%$ of normal subjects of similar ages would be expected to have lower two hour levels than the normal pressure hydrocephalus patients while $69.5 \%$ would be expected to have lower levels than the controls. 
Table 2 Two hour plasma glucose levels in normal pressure hydrocephalus patients and controls. Diabetes occurred in seventeen $(51.5 \%)$ of normal pressure hydrocephalus patients, but only four $(12.1 \%)$ of controls $(\mathrm{P}<0.01)$. The scoring system is described in the text

\begin{tabular}{|c|c|c|c|c|c|c|c|c|c|c|c|}
\hline \multicolumn{6}{|c|}{ Normal pressure hydrocephalus } & \multicolumn{6}{|c|}{ Controls } \\
\hline \multirow[b]{2}{*}{ Case } & \multirow[b]{2}{*}{$\operatorname{Sex}$} & \multirow[b]{2}{*}{ Age $(y r)$} & \multicolumn{2}{|c|}{ Two hour glucose } & \multirow{2}{*}{$\begin{array}{l}\text { Considered } \\
\text { diabetic }\end{array}$} & \multirow[b]{2}{*}{ Case } & \multirow[b]{2}{*}{$\operatorname{Sex}$} & \multirow[b]{2}{*}{ Age $(y r)$} & \multicolumn{2}{|c|}{ Two hour glucose } & \multirow{2}{*}{$\begin{array}{l}\text { Considered } \\
\text { diabetic }\end{array}$} \\
\hline & & & $(m g / d l)$ & $(\mathrm{mmol} / \mathrm{l})^{*}$ & & & & & $(m g / d l)$ & $(\mathrm{mmol} / \mathrm{l})^{*}$ & \\
\hline 1 & $\mathbf{M}$ & 50 & 120 & 6.7 & No & 1 & $\mathbf{M}$ & 50 & 76 & 4.2 & No \\
\hline 2 & $\mathbf{F}$ & 57 & 203 & 11.3 & Yes & 2 & $\mathbf{M}$ & 55 & 118 & 6.5 & No \\
\hline 3 & $\mathbf{F}$ & 57 & 190 & 10.5 & Yes & 3 & $\mathbf{F}$ & 56 & 77 & 4.3 & No \\
\hline 4 & $\mathbf{M}$ & 60 & 165 & 9.2 & No & 4 & $\mathbf{F}$ & 60 & 103 & 5.7 & No \\
\hline 5 & $\mathbf{M}$ & 61 & 256 & 14.2 & Yes & 5 & $\mathbf{M}$ & 60 & 69 & 3.8 & No \\
\hline 6 & $\mathbf{M}$ & 61 & 204 & 11.3 & No & 6 & $\mathbf{F}$ & 63 & 120 & 6.7 & No \\
\hline 7 & $\mathbf{F}$ & 63 & 168 & 9.3 & Yes & 7 & $\mathbf{M}$ & 64 & 146 & 8.1 & No \\
\hline 8 & $\mathbf{M}$ & 66 & 320 & 17.8 & Yes & 8 & $\mathbf{M}$ & 65 & 124 & 6.9 & No \\
\hline 9 & $\mathbf{F}$ & 67 & 180 & 10.0 & Yes & 9 & $\mathbf{F}$ & 66 & 71 & 3.9 & No \\
\hline 10 & $\mathbf{M}$ & 67 & 116 & 6.4 & No & 10 & $\mathbf{M}$ & 67 & 103 & 5.7 & No \\
\hline 11 & $\mathbf{F}$ & 67 & 240 & 13.3 & Yes & 11 & $\mathbf{F}$ & 67 & 97 & 5.4 & No \\
\hline 12 & $\mathbf{M}$ & 68 & 150 & 8.3 & No & 12 & $\mathbf{M}$ & 68 & 145 & 8.0 & No \\
\hline 13 & $\mathbf{M}$ & 68 & 195 & 10.8 & Yes & 13 & $\mathbf{F}$ & 68 & 200 & 11.1 & Yes \\
\hline 14 & $\mathbf{M}$ & 69 & 164 & 9.1 & No & 14 & $\mathbf{M}$ & 69 & 116 & 6.4 & No \\
\hline 15 & F & 69 & 167 & 9.3 & No & 15 & $\mathbf{M}$ & 71 & 100 & 5.6 & No \\
\hline 16 & $\mathrm{~F}$ & 70 & 124 & 6.9 & No & 16 & $\mathbf{F}$ & 72 & 80 & 4.4 & No \\
\hline 17 & $\mathbf{M}$ & 72 & 182 & 10.1 & Yes & 17 & $\mathbf{M}$ & 72 & 214 & 11.8 & Yes \\
\hline 18 & $F$ & 72 & 162 & 9.0 & No & 18 & $\mathbf{M}$ & 73 & 120 & 6.7 & No \\
\hline 19 & $\mathbf{M}$ & 72 & 165 & 9.2 & No & 19 & $\mathbf{F}$ & 73 & 110 & 6.1 & No \\
\hline 20 & $\mathbf{F}$ & 73 & 247 & 13.7 & Yes & 20 & $\mathbf{M}$ & 74 & 68 & 3.8 & No \\
\hline 21 & $\mathbf{M}$ & 74 & 165 & 9.2 & No & 21 & $\mathbf{M}$ & 74 & 80 & 4.4 & No \\
\hline 22 & $\mathbf{F}$ & 74 & 120 & 6.7 & No & 22 & $\mathbf{M}$ & 75 & 126 & 7.0 & No \\
\hline 23 & $\mathbf{M}$ & 74 & 135 & 7.5 & No & 23 & $\mathbf{F}$ & 75 & 178 & 9.9 & No \\
\hline 24 & $\mathbf{F}$ & 74 & 135 & 7.5 & No & 24 & $\mathbf{M}$ & 77 & 145 & 8.0 & No \\
\hline 25 & $\mathbf{M}$ & 75 & 400 & 22.2 & Yes & 25 & $\mathbf{M}$ & 77 & 106 & 5.9 & No \\
\hline 26 & $\mathbf{M}$ & 77 & 170 & 9.4 & No & 26 & $\mathbf{F}$ & 77 & 86 & 7.8 & No \\
\hline 27 & $\mathbf{F}$ & 77 & 236 & 13.1 & Yes & 27 & $\mathbf{M}$ & 77 & 178 & 9.9 & No \\
\hline 28 & $\mathbf{F}$ & 77 & 251 & 13.9 & Yes & 28 & $\mathbf{F}$ & 78 & 201 & 11.2 & Yes \\
\hline 29 & $\mathbf{M}$ & 79 & 175 & 9.7 & Yes & 29 & $\mathbf{M}$ & 78 & 118 & 6.5 & No \\
\hline 30 & $\mathbf{F}$ & 79 & 134 & 7.4 & No & 30 & $\mathbf{M}$ & 79 & 120 & 6.7 & No \\
\hline 31 & $\mathbf{M}$ & 82 & 197 & 10.9 & Yes & 31 & $\mathbf{M}$ & 81 & 162 & 9.0 & No \\
\hline 32 & $\mathbf{F}$ & 84 & 254 & 14.1 & Yes & 32 & $\mathbf{F}$ & 82 & 111 & 6.2 & No \\
\hline 33 & F & 84 & 272 & 15.1 & Yes & 33 & $\mathbf{F}$ & 84 & 173 & 9.6 & Yes \\
\hline
\end{tabular}

*SI Units.

\section{Comment}

The compelling evidence for a definite relationship between diabetes mellitus and normal pressure hydrocephalus was the frequency with which diabetic GTT occurred in normal pressure hydrocephalus patients $(51.5 \%)$ compared with controls $(12.1 \%)$. The incidence of diabetes in controls was slightly above the $6-7 \%$ prevalence reported for the age groups studied (Joslin, 1971), while that of the normal pressure hydrocephalus patients was approximately eight times greater than the expected prevalence.

Normal pressure hydrocephalus occurred in an older population. Abnormal GTT are found with increasing frequencies in older subjects who have no other signs of diabetes (Andres, 1971; Unger, 1957; Malins et al., 1963; Andres, 1971). However, the diabetes mellitus in these patients was not accounted for by their advanced ages, because comparison of their two hour glucose levels with the age-adjusted nomogram (Andres, 1971) revealed that their elevations were in excess of those attributable to increasing age. Hospitalisation, with subsequent physical inactivity, may result in a 'chemical diabetes' which disappears as soon as normal activity is resumed (Andres, 1971). However, hospitalisation-inactivity did not account for the $40 \%$ discrepancy in incidence of diabetes between the normal pressure hydrocephalus and control patients, because the control group came from a hospitalised population, many of whom had been in hospital for months. Thus, the relationship between normal pressure hydrocephalus and the diabetic state is not accounted for either by age or hospitalisation.

The earliest descriptions of normal pressure hydrocephalus hypothesised that the intraventricular pressure was elevated at an early stage in the development of the syndrome (Hakim and Adams, 1965; Adams et al., 1965). Subsequent studies of the temporal sequence of events leading to normal pressure hydrocephalus in dogs support this concept (James et al., 1973). Following subarachnoid injection of silastic, the intraventricular pressure initially increased as the ventricles enlarged. After 20-40 
days, the pressure gradually returned to normal but the ventricles remained enlarged. In most cases in humans the enlargement is generalised and includes lateral, third, and fourth ventricles as well as the aqueduct of Sylvius. As the expansion progresses, there must be compression of adjacent diencephalic and brainstem structures. Electric stimulation and ablation studies of hypothalamus, midbrain, and floor region of the fourth ventricle have produced hyperglycaemia and glycosuria in animals (Bernard, 1858; Banting et al., 1922; Sacks and MacDonald, 1925; Himwich and Keller, 1930; Macleod, 1934; David et al., 1935; Barris and Ingram, 1936; Anderson et al., 1952; Amand and Dua, 1955). In man, diabetes mellitus has occurred in conjunction with cysts or neoplasms of the midbrain, dienphalon, and roof of the third ventricle (Byrom and Russell, 1932; Vonderahe, 1937; Beck et al., 1966). In a remarkable case of intermittent aqueductal obstruction, there was severe diabetes mellitus which worsened with each acute exacerbation of internal hydrocephalus and resolved each time the pressure was relieved (Niemer and Vonderahe, 1940).

The same physiological mechanism may be at the basis of the diabetes mellitus produced experimentally and that occurring spontaneously in hydrocephalus, namely destructive or irritative involvement of hypothalamic and brainstem autonomic structures which carry glycogenolytic impulses to the liver, or supply the pituitary, adrenals, or pancreas (Best, 1961; Haymaker and Anderson, 1973). However, in most previous cases of hydrocephalus with diabetes mellitus, the hydrocephalus was acute, and the intraventricular pressure elevated. The same explanation may not apply in cases of normal pressure hydrocephalus where the hydrocephalus is more chronic and the intraventricular pressure has returned to normal.

The glucose tolerance test results were interpreted in part by Frank Barbarossa, MD, Department of Pathology, Millard Fillmore Hospital, Buffalo.

\section{References}

Adams, R. D., Fisher, C. M., Hakim, S., Ojemann, R. G., and Sweet, W. H. (1965). Symptomatic occult hydrocephalus with 'normal' cerebrospinal fluid pressure. New England Journal of Medicine, 273, 117-126.

Amand, B. K., and Dua, S. (1955). Blood sugar changes induced by electrical stimulation of the hypothalamus of the cat. Indian Journal of Medical Science, 43, 123-127.

Anderson, E., Rioch, D. Mek., and Haymaker, W. (1952). Disturbances in the blood sugar in animals subjected to transection of the brainstem. Acta Neurovegetativa, 5, 132-164.

Andres, R. (1971). Aging and diabetes. Medical Clinics of North America. 55, 835-846.
Andres, R. (1971). The effect of age in interpretation of $\bar{z}$ glucose and tolbutamide tolerance tests. In Diabetes Mellitus. Vol. 3, pp. 115-120. Edited by S. S. Fajansō̄ and K. B. Sussman. American Diabetes Association:? New York.

Banting, F. G., Best, C. H., Collip, J. B., Macleod, J. J.R., and Noble, E. C. (1922). The effects of insulin on experimental hyperglycemia in rabbits. American $\subseteq$ Journal of Physiology, 62, 559-580.

Barris, R. W., and Ingram, W. R. (1936). The effect of experimental hypothalamic lesions on blood sugar. American Journal of Physiology, 114, 555-561.

Beck, P., Parker, M. L., and Doughaday, W. H. (1966). Paradoxical hypersecretion of growth hormone in $\frac{C}{0}$ response to glucose. Journal of Clinical Endocrinology $\overline{\overline{0}}$ and Metabolism, 26, 463-469.

Bernard, C. (1858). Vingt-troisième leçon. In Leçons sur $\AA$ la Physiologie et la Pathologie du System Nerveux. œ Vol. 1, pp. 448-462. Edited by J. B. Baillière et fils, $\vec{O}$ Paris.

Best, C. H. (1961). Carbohydrate metabolism. In The $\overrightarrow{\vec{H}}$ Physiologic Basis of Medical Practice. pp. 830-835. Edited by C. H. Best and N. B. Taylor. Williams and Wilkins: Baltimore.

Byrom, F. B., and Russell, D. J. (1932). Ependymal cyst of the third ventricle. Lancet, 223, 278-282.

David, L., Cleveland, D., and Ingram, W. R. (1935). Carbohydrate metabolism: the effect of hypothalam lesions and stimulation of the autonomic nervo 0 system. Archives of Neurology and Psychiatry (Chicagof, 33, 592-615.

Hakim, S., and Adams, R. D. (1965). The special clinicol problems of symptomatic hydrocephalus with norma cerebrospinal fluid pressure: Observations on cerebre. spinal fluid hydrodynamics. Journal of the Neurologic Sciences, 2, 307-327.

Haymaker, W., and Anderson, E. (1973). Disorders of the hypothalamus and pituitary gland. In Clinical Neurology. Vol. 2, pp. 27-79. Edited by A. B. Baker and L. H. Baker. Harper and Row Publishers: New York.

Helper, D. E. (1966). Manual of Clinical Laboratory Methods. pp. 269-270. Charles C. Thomas: Springfield.

Himwich, H. E., and Keller, A. D. (1930). Effect of stimulation of hypothalamus on blood glucose. American Journal of Physiology, 93, 658-662.

International System of Units. (1972). National Bureau of Standards, Special publication 330. United States Bureau of Printing: Washington.

Jacobs, L., Conti, D., Kinkel, W. R., and Manning, E. J. (1976). Normal pressure hydrocephalus: relationship of clinical and radiographic findings to improvement following shunt surgery. Journal of the American Medical Association, 235, 510-512.

Jacobs, L., and Kinkel, W. R. (1976). Computerised axial transverse tomography in normal pressure hydrocephalus. Neurology (Minneapolis), 26, 501-507.

James, A. E., Strecker, E. P., Novak, G., and Burns, B. N (1973). Correlation of serial cisternograms and cerebrospinal fluid measurements in experimental communicating hydrocephalus. Neurology (Minneapolis), 23, 1226-1233. 
Joslin's Diabetes Mellitus. (1971). p. 12. Edited by A. Marble, P. White, R. F. Bradley, and L. P. Krall. Lea and Febiger: Philadelphia.

Klimt, C. R., Prout, T. E., Bradley, R. F., Dolger, H., Fisher, G., Gastineau, C. F., Marks, H., Meinert, C. L., and Schumacher, O. P. (1969). Standardisation of the oral glucose tolerance test. Report of the committee on statistics of the American Diabetes Association. Diabetes, 18, 299-307.

Macleod, J. J. R. (1934). The control of carbohydrate metabolism. Bulletin of Johns Hopkins Hospital, 54, 79-139.

Malins, J. M., Fitzgerald, M. G., and Gaddie, R. (1963). Glucose tolerance and glycosuria in the general population. British Medical Journal, 2, 655-659.

Matthews, W. B. (1958). Metabolic disease of the nervous system, clinical aspects. Proceedings of the Royal Society of Medicine, 51, 859-863.

Niemer, W. T., a nd Vonderahe, A. R. (1940). Cyst of the pulvinar of the thalamus: report of a case with obstructive internal hydrocephalus and diabetes mellitus of intermittent severity. Archives of Neurology and Psychiatry (Chicago), 44, 1086-1092.
Sacks, E., and MacDonald, M. E. (1925). Blood sugar studies in experimental pituitary and hypothalamic lesions with a review of the literature. Archives of Neurology and Psychiatry (Chicago), 13, 335-368.

Schalch, D. S., McFarlin, D., and Barlow, M. H. (1970). An unusual form of diabetes mellitus in ataxia telangiectasia. New England Journal of Medicine, 282, 1396-1402.

Steinke, J., and Taylor, R. (1964). The association of amyotrophic lateral sclerosis and carbohydrate intolerance, a clinical study. Metabolism, 13, 1376-1381.

Unger, R. H. (1957). The standard two hour glucose tolerance test in the diagnosis of diabetes mellitus in subjects with fasting hyperglycemia. Annals of Internal Medicine, 47, 1138-1153.

Vonderahe, A. R. (1937). Central nervous system and sugar metabolism: clinical, pathological and theoretical considerations with special reference to diabetes mellitus. Archives of Internal Medicine (Chicago), 60, 694-704.

Zalme, E., and Knowles, H. C. Jr. (1965). A plea for plasma sugar. Diabetes, 14, 165-166. 
Infantile Spasms By Joseph R. Lacy and J. Kiffin Penry. (Pp. 169; price not stated.) Raven Press: New York. 1976. Predictability in Psychopharmacology -Preclinical and Clinical Correlations Edited by Abraham Sudilovsky, Samuel Gershon, and Bernard Beer. (Pp. 303; illustrated; \$22.50.) Raven Press: New York. 1975.

Complex Partial Seizures and Their Treatment. Advances in Neurology Vol. 11 Edited by J. Kiffin Penry and David D. Daly. (Pp. 472; illustrated; \$24.95, Dfl.62.00.) Raven Press: New York. 1976.

Blood-Brain Barrier in Physiology and Medicine By Stanley I. Rapoport. (Pp. 316; illustrated; \$28.00.) Raven Press: New York. 1976.

Clinical Pharmacology of Serotonin Monographs in Neural Sciences Vol. 3. Series Editor Maynard M. Cohen, Volume Editors F. Sicuteri and E. Schonbaum. (Pp. 139; illustrated; \$24.75.) Karger: Basel. 1976.

Anaesthesie und ZNS Technische Gefahren der Anaesthesie Medikamentose Wechselwirkungen Massivttransfusion By $H$. Bergmann and $B$. Blauhut. (Pp. 191; illustrated; \$32.50.) Karger: Basel. 1976.

Psychiatriatrie und Psychosomatik By N. Petrilowitsch. (Pp. 191; illustrated; \$32.50.) Karger: Basel. 1976.

Proceedings XVIth International Congress of Logopedics and Phoniatrics Interlaken 1975. Edited by E. Ooebell. Bern. (Pp. 550; illustrated; \$69.25.) Karger: Basel. 1976.

Neuroendocrine Regulation of Fertility Edited by T. C. A. Kumar. (Pp. 322; illustrated; \$59.00.) Karger: Basel. 1976.

Institutional Neurosis Third Edition. By R. Barton. (Pp. 83; illustrated; £3.00.) Wright: Bristol. 1976.

Apes, Men and Language By Eugene Linden. (Pp. 304; illustrated; 90 pence.) Penguin: Harmondsworth. 1976.

Punishment-The Supposed Justifications By Ted Honderich. (Pp. 210; £2.25.) Penguin: Harmondsworth. 1976. Structura Si Functile Sistemukui Nervos Central By A. Kreindler. (Pp. 459; illustrated; price not stated.) Editura Academiei: Romania. 1976.

New Directions in Sex Research Edited by E. A. Rubinstein, R. Green, and E. Brecher. (Pp. 172; \$23.40.) Plenum: New York and London. 1976. Zerebrale Bewegungs-störungen im
Kindesalter By W. Kressin and $M$. Rautenbach. (Pp. 152; illustrated; DDRm.11.00.) Verlag Volk und Gesundheit: Berlin. 1976.

Psychoanalyse heute Theorie und Praxis in ihren Grundziigen Edited by T. F. Hau and H. G. Arnds. (Pp. 191; price not stated.) Hippokrates Verlag: Stuttgart. 1977.

Informationsverarbeitung im Zentralnervensystem Edited by Wolfgang Haschke. (Pp. 252; illustrated; Dm.60.00.) Gustav Fischer Verlag: Jena. 1976.

Electrodiagnosis-A Handbook for Neurologists By Mario P. Smorto and John V. Basmajian. (Pp. 163; illustrated; \$16.95.) Harper and Row: New York. 1977.

Families and Family Therapy By Salvador Minuchin. (Pp. 268; £2.90.) Tavistock Publications: London. 1977.

Child Guidance and Delinquency in a London Borough By Dennis Gath, Brian Cooper, Frank Gattoni, and Dorothy Rockett. (Pp. 190; illustrated; £7.00.) Oxford University Press: London. 1977.

\section{Notices}

The Association for Research in Nervous and Mental Disease, Inc. will hold its Annual Meeting on 2 and 3 December 1977 at the Hotel Biltmore in New York City. This meeting will be devoted to Congenital and Acquired Cognitive Disorders.

Dr Robert Katzman is the President and Chairman of this year's Commission. A distinguished group of scientists will review the clinical spectrum and management of diseases that produce amentias in the young and dementias in the adult and the elderly. Special attention will be given to biological issues in the genesis of early infantile autism and the role of perceptual loss as a cause of cognitive dysfunction. An analysis of the morphological and physiological development of language and cognitive function will provide a basis for understanding the changes that occur in disease. The nature of the biochemical basis of amentias and the consequent aberrant development of cortical neurones occurring in the course of metabolic disorders will be contrasted with the biochemical, morphological, and ultrastructural changes that occur in Alzheimer's disease/senile dementia. The role of genetic factors and latent viral diseases in the aetiology of amentias and dementias will be considered.

Further information about this meet-. ing can be obtained from the SecretaryTreasurer of the ARNMD, Dr Roger Duvoisin, Association for Research in Nervous and Mental Disease, Inc, Annenberg Building, Suite 14-02, 100th Street at 5th Ave., New York, New York 10029, USA.

A Neurological Conference will be held at the University of Sussex under the auspices of the Centre for Medical Research at the University from Thursday 6 to Saturday 8 April 1978. Subjects to be discussed are Pain, Neuropharmacology of the Basal Ganglia, Epilepsy, Brain and Behaviour, Virus Disease of the Nervous System, and Multiple Sclerosis. Further information can be obtained from Dr Simon Nurick, HurstWood Park Neurological Centre, Haywards Heath, West Sussex RH17 7SJ, England.

The Second World Congress on Pain will be held at the Queen Elizabeth Hotel, in Montreal, Canada, from Sunday 27 August to Friday 1 September 1978. All enquiries about the Congress should be addressed to the Secretariat, Second World Congress on Pain, 3587 University Street, Montreal, Quebec H3A 2B1, Canada. Telephone (514) 392-6747. Telex 05-268510.

\section{Correction}

Jacobs, L. (1977). Diabetes mellitus in normal pressure hydrocephalus. Journal of Neurology, Neurosurgery, and Psychiatry, 40, 331-335.

In the section headed CRITERIA FOR DIAGNOSIS OF DIABETES MELLITUS On page 332 the number 20 should have been 30 . 